\title{
Conservation Constraints and Strategies of the Arba Minch Forest Nech Sar National Park: Arba Minch, Ethiopia
}

\author{
Selemon Thomas Fakana ${ }^{1, ~}$, Debebe Dana Feleha ${ }^{2}$ \\ ${ }^{1}$ College of Agriculture and Natural Resources, Gambella University, Gambella, Ethiopia \\ ${ }^{2}$ College of Agriculture, Wolaitta Soddo University, Wolaita Sodo, Ethiopia
}

\section{Email address:}

selethom36@gmail.com (S. T. Fakana)

${ }^{*}$ Corresponding author

\section{To cite this article:}

Selemon Thomas Fakana, Debebe Dana Feleha. Conservation Constraints and Strategies of the Arba Minch Forest Nech Sar National Park: Arba Minch, Ethiopia. International Journal of Environmental Monitoring and Analysis. Vol. 8, No. 4, 2020, pp. 96-110.

doi: $10.11648 /$ j.ijema.20200804.13

Received: May 19, 2020; Accepted: May 28, 2020; Published: August 27, 2020

\begin{abstract}
Human beings are utterly dependent on nature particularly on the forest ecosystem services. Our health, economy, prosperity, and development are all connected to the forest ecosystem services. Forest ecosystems afford variety of the ecosystem services that human beings depend up on them. Ecosystem services are base for the survival of mankind and play significant role in economic development, prosperity, health, etc. Arba Minch Forest ecosystem is a crucial asset that maintains the continuity and survival of the Arba Minch town and its environs. Despite its tangible and worthy ecosystem services, it has been exposed to the conservation constraints due to the anthropogenic activities. However, limited studies have been conducted on its conservation constraints and strategies. Hence, this study focuses on identifying conservation constraints and finding out conservation strategies. Accordingly, the study was carried out using four sample categories (Arba Minch town residents households $(n=151)$, key informants $(n=21)$, accommodations delivers $(n=9)$ and peoples entering into the forest $(\mathrm{n}=21)$ ) besides to field observation. Altogether $(\mathrm{n}=199)$ peoples involved in this study. Collected raw data were chosen, refined, categorized edited, coded and entered to SPSS version 20 software. Descriptive statistics were computed for relevant variables and information obtained from the key informants was described in meaningful content. Findings of this study revealed that in spite of its undeniable ecosystem services, conservation constraints are ongoing like deforestation, dependence of households and accommodation delivers, lack of alternative livelihood generation, and so on. Hence, to overcome the stated constraints; putting into practice variety of the identified conservation strategies like enhancing public awareness, stakeholders' participation, providing alternative livelihood generation, ensuring alternative energy sources, etc. are core activities to save the forest and sustain its ecosystem services.
\end{abstract}

Keywords: Arba Minch Forest, Conservation Constraints, Conservation Strategies

\section{Introduction}

Forest ecosystems are very important for social, economic and ecological reasons. They play an important role in ecosystem processes, air pollution abatement and ground water recharge [1]. In this era of global warming, forest ecosystems help mitigate the effects of climate change [2]. Ecosystems and the biological diversity contained within them provide a stream of goods and services, the continued delivery of which remains essential to our economic prosperity and other aspects of our welfare [3]. In a broad sense, ecosystem services refer to the range of conditions and processes through which natural ecosystems, and the species that they contain, help sustain and fulfill human life [4]. The four broad categories of forest ecosystem services are: provisioning, such as the production of food and water; regulating, such as the control of climate, flood and diseases; supporting/habitat, such as nutrient cycles and crop pollination; and cultural, such as spiritual and recreational benefits [5]. 
National parks are the most extensive type of protected areas in Africa and globally. They are classified under category II of the World Conservation Union (IUCN) categories of protected areas. National parks are created to (1) protect the ecological integrity of one or more ecosystems for present and future generations; (2) exclude exploitation or occupation for the better conservation of the natural resources; and (3) provide spiritual, scientific, educational, recreational, and ecological opportunities, all of which must be environmentally and culturally compatible [6].

Nech Sar National Park (NSNP) is an IUCN category II national park that was established in 1974 with the aim of conserving the vast diversity of wildlife and the scenic beauty of the area. It is located in Southern Nations Nationalities and People's Region (SNNPR) immediately to the east of Arba Minch town, having distance of $510 \mathrm{~km}$ from the capital city Addis Ababa. The park covers $514 \mathrm{~km}^{2}$ of territory including the "Bridge of God" (an isthmus between Lakes Abaya and Chamo). The park's elevation ranges from 1108 to 1650 meter above sea level [7].

The park provides various ecosystem services like provisioning services (food, water, timber, fuel wood, fodder, grass, charcoal, medicinal plants, etc.), regulatory services (air quality regulation, fresh air provision, flood prevention, pollination, etc.), habitat services for wild fauna like Primate species (Colobus monkey, Anubis Baboon, Vervet Monkey), Common Bushbuck, Warthog, Klipspringer, Waterbuck, Leopard, etc. and cultural services like recreation, ecotourism, bird watching, forest walking, mountain climbing, trekking, aesthetic value and spiritual relaxation [8]. The vegetation in the park consists of the forest ecosystem, grasslands, shrub lands and thickets, woodlands and so on. There are also savannah, mountain habitats and spectacular landscapes. Hence, it has variety of ecosystem units that supports the vast diversity of wildlife and provides a number of crucial ecosystem services for the human wellbeing [9].

The Arba Minch Forest ecosystem is the "lung" of the Arba Minch town and its vicinities. It is the best component of Nech Sar National Park and is unique in its vegetation formation from which the miracle forty springs emanates. It comprises naturally roofed forest which forms an attractive and diverse evergreen habitat near to forty springs which is called as "God's Hall" [10]. It provides regulatory services like purification of forty springs, maintenance of fresh air, carbon sequestration, waste decomposition, maintenance of soil fertility, pest and disease control, etc. This forest satisfies the spiritual, recreation and aesthetic needs. It serves as cultural asset and the "green home" for diversified wild fauna and flora species with exceptional nutrient cycles and energy flows [11]. Moreover, Arba Minch Forest also provides food (game, fruit, flowers), drinking water to the whole Arba Minch town, raw materials (fuel wood, charcoal, fodder, grass, timber, etc.), and so on. Hence, the ecosystem services of the Arba Minch Forest are unforgettable on behalf of the progenies of the human being as well as species of the wild fauna and flora.

Nevertheless, nowadays, anthropogenic activities are posing challenges to the above mentioned worthy and undeniable ecosystem services of the Arba Minch Forest. With increasing human population, the demand for fuel wood and charcoal for household consumption and commercial activities challenge this forest immensely [12, 19]. Furthermore, its ecosystem services are often undervalued or are not given due attention by public decision-makers, investors, local communities, tourist accommodation providers, etc. The lack of clear understanding of and relevant information on the values of ecosystem services has generally led to neglect of Arba Minch Forest ecosystem in public decision making as well as in public perception [11, 10]. However, limited study has been conducted on the major conservation challenges that it has been facing and finding potential conservation strategies for the sustainable conservation of the Arba Minch Forest ecosystem. Therefore, this study focuses on identifying major conservation challenges and finding out potential conservation strategies to enhance sustainable conservation of Arba Minch Forest in the Nech Sar National Park to ensure the sustainability of its ecosystem services.

\section{Methodology}

\subsection{Study Area Description}

Nech Sar National Park (NSNP; location between $5^{\circ} 51^{\prime}$ $6^{\circ} 10^{\prime} \mathrm{N}$ and $37^{\circ} 32^{\prime}-37^{\circ} 48^{\prime} \mathrm{E}$ ) is situated at the middle of Ethiopia Great Rift Valley, at $510 \mathrm{~km}$ south of Addis Ababa [8]. It is established in 1974 and covers an area of $514 \mathrm{~km}^{2}$, of which $15 \%$ is covered by water bodies (lakes Chamo and Abaya) (Figure 1). Elevation in the park ranges from 11081650 meter above sea level. The annual average rainfall in the area is $880 \mathrm{~mm}$ and average maximum and minimum temperature is $300^{\circ} \mathrm{C}$ and $17^{\circ} \mathrm{C}$, respectively [12]. The park contains more than 90 mammal species, and supports more than 350 species of birds as a result of which the park has been designated as one of the sixty-nine Important Bird Areas in Ethiopia [8]. This study was conducted on the Arba Minch Forest, which is located in the western part of the park closer to the Arba Minch town, from September to June, 2017. This evergreen forest is the source of forty natural springs, locally known as Arba Minch (meaning 'forty springs'); hence the name for Arba Minch town is derived from these streams [10]. Arba Minch town consists of 4 subcities which together comprise 11 kebeles (= village or the lowest town administration unit). Based on 2007 housing and population census, this town has a total population of 114,355 (58,562 male and 55,793 female) with average growth rate of $2.9 \%$ [13]. 


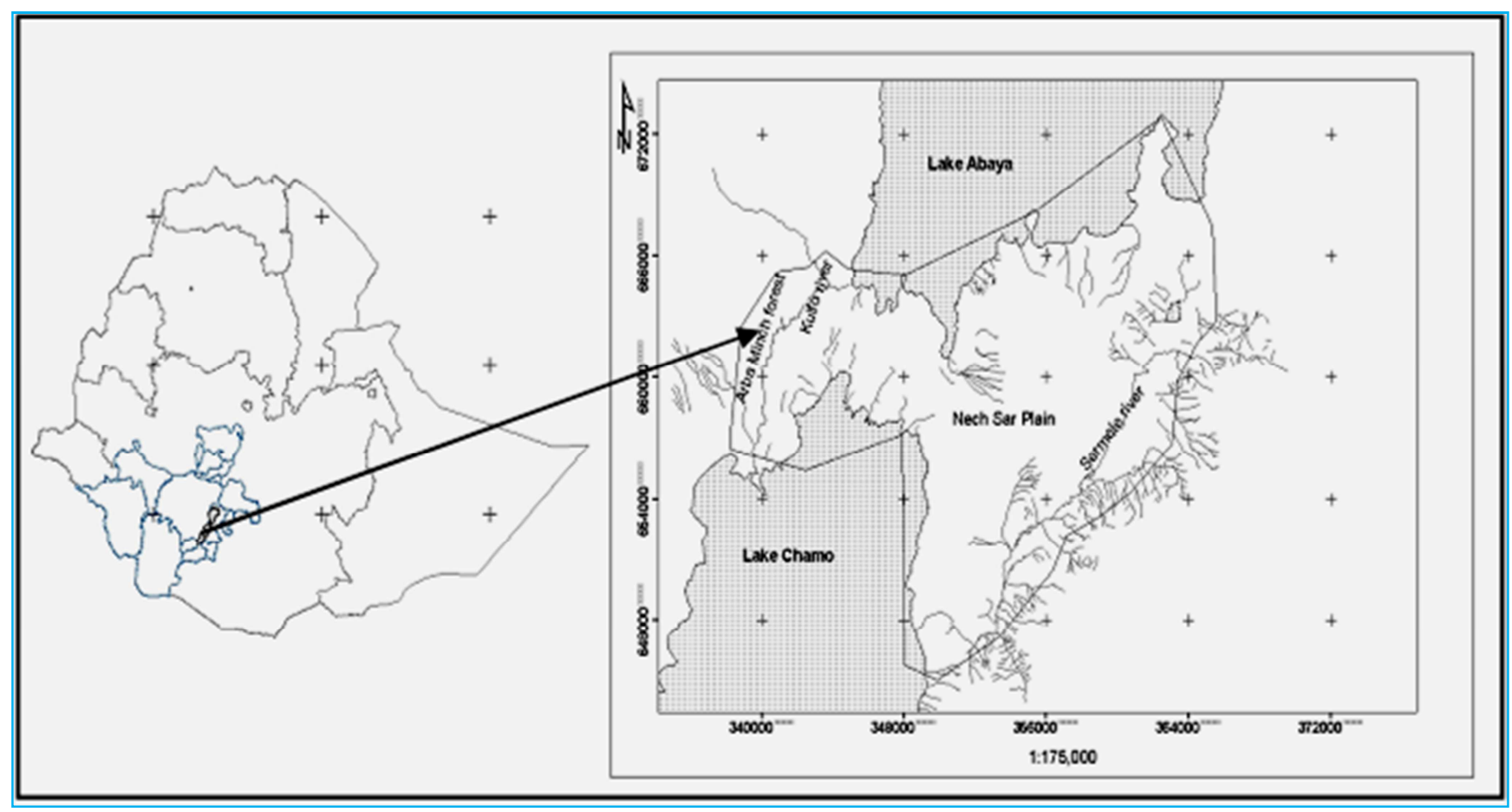

Source: - Fetene A, Tsegaye T and Pananjay KT (2012)

Figure 1. Map of the study Area.

\subsection{Sampling Design}

In this study both probability sampling (systematic and simple random sampling - to select household respondents) and non-probability sampling (purposive sampling - to select key informants, quota sampling - to select household respondents, snowball sampling - to select private business organizations and haphazard/convenience/chunk sampling to select peoples entering into Arba Minch Forest) was adopted. Semi-structured interview and key informants discussion methods were used for data collection. People used for interviews were selected from Arba Minch town residents/households. Besides to this, key informants discussion was held with seven relevant institutions/organizations in the town. They were included from government/public organizations (Arba Minch Town Water Supply Department, Nech Sar National Park, Gamo Gofa Zone Agriculture and Schools), private business organizations (hotel/lodge companies and ecotourism associations), and civil societies (nature clubs).

Three kebeles, one from each three sub-cities (i.e. Dilfana kebele from Sikela sub-city, Shecha from Chamo and Nech Sar from Wuha Minch), were selected as target population for this study. The total populations of the three kebeles (Chamo, Wuha Minch and Dilfana) were 1586, 1690 and
1747, respectively. These kebeles are found adjacent to the park and bordering the Arba Minch Forest, and are where most tourism service providers (hotels, lodges and restaurants and ecotourism associations) are located. Thus, these kebeles were selected purposively assuming that using residents of these kebeles would help us minimize logistic requirements (financial and time) while collecting adequate data needed to meet the objectives of the study.

Accordingly, thesample size was determined by using the formula derived by Kothari (2004) as follows.

$$
\mathrm{n}=\frac{\mathrm{Z}^{2} \mathrm{pqN}}{\mathrm{e}^{2}(\mathrm{~N}-1)+\mathrm{Z}^{2} \mathrm{pq}}
$$

Where: $\mathrm{n}$ : is the sample size for a finite population.

$\mathrm{N}$ : target population size (the number of households) which is 5023 .

$\mathrm{p}$ and $\mathrm{q}$ : are population proportion (frequency estimated for a sample of size $n$ ), where $p$ and $q$ is 0.5 each for $50 \%$ of response distribution.

e: margin of error or sampling error which is considered is $7 \%$ for this study.

$\mathrm{Z}$ : The value that specifies the level of confidence at 0.07 is 1.81 .

Hence, the sample size at $93 \%$ of confidence level was:

$$
\begin{aligned}
\mathrm{n}=\frac{\mathrm{Z}^{2} \mathrm{pqN}}{\mathrm{e}^{2}(\mathrm{~N}-1)+\mathrm{Z}^{2} \mathrm{pq}} & =\frac{(1.81) 2(0.5)(0.5)(5023)}{(0.07) 2(5023-1)+(1.81) 2(0.5)(0.5)}=\frac{(3.2761)(0.25)(5023)}{(0.0049)(5022)+(3.2761)(0.25)} \\
& =\frac{4113.9625}{24.6078+0.819025}=\frac{4113.9625}{25.4268}=161.7963=162
\end{aligned}
$$

However, According to Cochran (1963), Finite Population Correction for Proportions is possible. If the population is 
small then the sample size can be reduced slightly. This is because a given sample size provides proportionately more information for a small population than for a large population. The sample size $\left(\mathrm{n}_{0}\right)$ can be adjusted using the following equation, $\mathrm{n}=\frac{\mathrm{n}_{\mathrm{o}}}{1+\left(\mathrm{n}_{0}-1\right) / \mathrm{N}}$

Where: $\mathrm{n}=$ required sample size

$\mathrm{n}_{\mathrm{o}}=$ sample size without finite population correction for proportions

$1=$ constant

$\mathrm{N}=$ the target population size

Thus, the final sample size at $93 \%$ of confidence level was:

$$
\mathrm{n}=\frac{\mathrm{n}_{\mathrm{o}}}{1+\frac{\left(\mathrm{n}_{\mathrm{o}}-1\right)}{\mathrm{N}}}=\frac{162}{1+\frac{(162-1)}{5023}}=\frac{162}{1+0.0321}=\frac{162}{1.0321}=156.96=157
$$

Hence, total sample size of household respondents from three kebeles was determined applying Quota Sampling technique to determine sample size from each kebeles with probability proportional to their population size. Accordingly, 49, 53 and 55 householders (total $=157$ ) were selected from Chamo, Wuha Minch and Dilfana kebeles, respectively. Systematic sampling method was used to select individual respondent for interview. To do so, we first computed sampling interval (which was 31) as the ratio of the 'target population $=5023$ ' to the 'required sample size $=157$ '). Then, each household in each kebele was given a numerical code. Based on this code, the first respondent in each kebele was randomly selected and then subsequent individuals were interviewed at every 31 interval (Cochran, 1963).

Key informants $(n=21)$ from government offices were selected purposively based on their experience and knowledge of the area. Likewise, key informants from peoples entering into the Arba Minch Forest $(n=21)$ selected using haphazard/convenience/chunk sampling. Furthermore, private business organizations $(\mathrm{n}=9)$ selected using snowball sampling technique. Accordingly, interviewing was started with the initial person who meets the criteria for inclusion in the study. The first respondent would be led about other additional member with a similar interest or knowledge. Subsequently, the next respondent interviewed. Next respondent was accessed on the recommendation of second respondent. This chain was continued further as needed. Overall, 208 people were consulted in the study.

\subsection{Data Collection and Analysis}

Interviews were carried out with the assistance of experienced experts working in the NSNP. Nonetheless, to further ensure reliable data be collected, these interviewers were trained prior to data collection on the concept and objectives of the study, the meanings and concepts of the interview questions presented and data recording procedures. The questions administered were semi-structured, with open- or close-ended types, and coarsely divided into three sections: respondents' socio-economic status, key conservation constraints and potential conservation strategies. Similar questions were used for discussions held with key informants, but the questions were in unstructured, openended (probing) and informal ways.

Collected raw data were chosen, refined, categorized edited, evaluated, coded and entered to SPSS (Statistical Package for Social Sciences) software and Microsoft Excel spreadsheet. Descriptive statistics such as frequencies and percentages were computed for relevant variables and presented using tables, graphs, charts, etc. and described in meaningful content. Information obtained from the key informants was not included for these computations, rather was used to cross-check and validate the responses and opinions reflected by the respondents.

\section{Results and Discussion}

\subsection{Socio-demographics}

Of the total 208 people consulted, nine samples (six from the household respondents and three from key informants) were incomplete. These were discarded and only data obtained from 199 samples were reported here. Majority of sampled people were males (150 people, or $75 \%$ of the total) and within age categories of $35-45$ years $(83 ; 42 \%)$, followed by $46-55$ years $(51 ; 26 \%)$ (Table 1$)$. Three-fourth of them $(151 ; 76 \%)$ were married and over $63 \%$ earn the lowest monthly income $(<1000$ ETB). Over $40 \%$ of the people were unschooled (cannot read/write), only $\sim 27 \%$ of them have completed their higher institutions education (i.e. above high school level) (Table 1).

Table 1. Socio-economic characteristics of the sampled population (total $=199$ people).

\begin{tabular}{|c|c|c|c|c|c|c|c|c|}
\hline Variable/category & Number & Percent & Variable/category & Number & Percent & Variable/category & Number & Percent \\
\hline a) Sex & & & c) Marital status & & & e) Education level & & \\
\hline Male & 150 & 75 & Married & 151 & 76 & Illiterate & 86 & 43 \\
\hline Female & 49 & 25 & Divorced & 19 & 10 & Can read/write & 36 & 18 \\
\hline b) Age & & & Widowed & 16 & 8 & Primary school & 24 & 12 \\
\hline $18-25$ & 8 & 4 & Single & 13 & 7 & Secondary school & 20 & 10 \\
\hline $26-35$ & 44 & 22 & d) Income * & & & Higher institution** & 33 & 17 \\
\hline $36-45$ & 83 & 42 & $<1000$ & 126 & 63 & & & \\
\hline $56-65$ & 9 & 5 & $2001-3000$ & 23 & 12 & & & \\
\hline$>65$ & 4 & 2 & $>3000$ & 19 & 10 & & & \\
\hline
\end{tabular}

* In Ethiopian Birr (ETB); ** received training in certificate and above diploma levels

Source: Field Survey $(2017 / 18)$ 


\subsection{Conservation Constraints}

\subsubsection{Lack of Awareness and Clear Understanding of the Values and Ecosystem Services}

Among the households respondents $(n=151)$, about 57 $(37.75 \%)$ are tried to explain the ecosystem services and values of the Arba Minch Forest ecosystem. On the other hand, in frequency 27 (17.88\%) of the household respondents are attempted to distinguish the differences between provisioning, regulatory, cultural and habitat services of the Arba Minch Forest ecosystem. So, small percentage of the household respondents has awareness, understanding and knowledge regarding the ecosystem services and existence values of the Arba Minch Forest ecosystem. For instance, a household respondent with ID No./code WHHN0674 explained as follows.

"In my opinion, the term ecosystem service of the Arba Minch Forest ecosystem refers to the services like firewood, charcoal, water, fruits, flowers, maintenance of fresh air, tourist attraction, etc."

Similarly, another household respondent with ID No./code DHHN0812 and DHHN1153 are respectively explained ecosystem services and values of the Arba Minch Forest ecosystem as follows.

"We depend on the Arba Minch Forest for our energy sources, water, food, construction materials, etc., besides to its provision of fresh air to the town and shelter for the wild animals."

"I can tell you that Arba Minch Forest provides for us firewood, water, food, charcoal, and it gives fresh air and spiritual satisfaction."

In same manner, about 27 (17.88\%) household respondents tried to distinguish the differences between provisioning, regulatory, cultural and habitat services of the Arba Minch Forest ecosystem. For instance, a household respondent with ID No./code CHHN1220 is explained as follows.

"In my understanding, provisioning services are like water, food, construction materials, firewood, etc.; regulatory services are like provision of fresh air; habitat services are like shelter for various wildlife and cultural services are like mental and spiritual satisfaction."

More or less in similar way, the other household respondent with ID No./code CHHN0259 tried to distinguish with confusion as under.

"Even though I don't know their differences clearly, what I know is that Arba Minch Forest provides energy sources (firewood, charcoal), water, food, construction materials, and it regulates and gives fresh air, home of various wild animals, and when you visit, it gives spiritual satisfaction."

One can understand from the above statements that most of the household respondents can explain that provisioning services of the Arba Minch Forest. his shows that they have limited awareness, knowledge and understanding regarding the ecosystem services and their differences. This statement is supported by a key informant with the ID No./code NSNP3 as follows.

"People can tell you that Arba Minch Forest ecosystem provides firewood, charcoal, water, etc. however, they can't differentiate the regulatory, cultural, habitat and provisioning services clearly."

In general, the above statements tell us that there is lack of awareness, knowledge and clear understanding of the local communities regarding the ecosystem services of the Arba Minch Forest ecosystem. Therefore, it needs further awareness creation, teaching, training, etc. of the local community. In support of this statement, a key informant with ID No./code NSNP2 explains as below.

"If you ask everybody in the Arba Minch town, he/she may respond that Arba Minch Forest is crucial for the Arba Minch town. but, I can say that Arba Minch Forest ecosystem services are beyond our explanation, and it needs further awareness creation, education, training, scientific study, etc."

\subsubsection{Lack of Recognition, Coordination and Commitment Among Stakeholders for Conservation}

Despite the undeniable ecosystem services of the Arba Minch Forest ecosystem, it has frequently been seen in isolation among stakeholders. Decision makers have been focused on reducing poverty, increasing food production, ensuring health care, education, etc. Conserving Arba Minch Forest ecosystem requires strong political commitment and an understanding of the value of its ecosystem services. According to respondents' response, it appears that commitment, recognition and coordination is lacking among stakeholders. In favor of this idea, a key informant with ID No./code CCL3 gives explanation as follows.

“... Despite its valuable ecosystem services, Arba Minch Forest is usually undervalued, not recognized and lacks priority for the conservation among the all concerned stakeholders, rather they give priority for other developmental projects like infrastructures, housing, food security, good governance, education, health care, etc., and they collaborate and give value and recognition to implement such activities."

\subsubsection{Insufficient Human Resource and Capacity Building for Conservation Activities}

Currently, there are four core processors (warden, experts, conservation and monitoring case teams or scouts and supporting workforce) with respective case teams. According to NSNP Human Resource Department (2017), about $66.67 \%, 56.25 \%, 27.27 \%$ and $27.03 \%$ are vacant positions of the core processors of warden, experts, conservation and monitoring case teams (scouts) and supporting workforces respectively. This indicates that there is insufficient human resource particularly in experts (professionals) and leaders. In general, about $31.97 \%$ is vacant positions which need urgent recruitment of human resource for sustainable conservation of the Arba Minch Forest. This issue is emphasized by a key informant with ID No./code NSNP3 as follows.

"There are a number of entry points (Kulfo Bridge, kontir, highland areas, motor sefer, ket ket, etc.) to the Arba Minch Forest ecosystem from the town as well as 
surrounding areas. But, the current human resources for the conservation activities, to control illegal activities and to control entry points are inadequate. Besides, it needs capacity building to develop influential conservationists (leaders, experts, rangers, supporting staff force, etc.)."

Furthermore, there is also high turnover of professionals or skilled man power in Nech Sar National Park. The reason of flow of skilled man power is that incompatible salary and benefits compared to their work, lack of adequate field facilities, insignificant capacity building, etc.

\subsubsection{Inadequate Investment in Training, Education and Research Activities}

Even though some researches has been conducted in the Arba Minch Forest ecosystem in specific issues; it is inadequate and has not pointed out sustainable conservation strategies. Still now, there are limited studies that have been conducted on the conservation constraints that it has been facing and potential conservation strategies. As a result, challenges are intensifying due to lack of awareness, clear understanding, recognition and commitment among stakeholders as well as local communities. In support of this issue a key informant with ID No./code NSNP1 describes as beneath.

"Still, different researches have been carried out on the Arba Minch Forest. Nevertheless, it needs further and deep research on its ecosystem services, conservation constraints it has been facing, valuation of the ecosystem services, potential conservation strategies for sustainability, etc."

\subsubsection{Deforestation}

In spite of conservation and monitoring activities of the Nech Sar National Park management as well as concerned stakeholders, Arba Minch Forest has been posing deforestation for a years. Since it is a matter of survival of the poor local communities, deforestation of Arba Minch Forest is becoming unstoppable. If you chase, punish, take to the court, etc., they may not stop deforestation since they are familiarized with those punishment methods. Due to lack of alternative livelihood generation option, poor local communities practice deforestation. Among household respondents, about $140(15.37 \%)$ indicated that lack of alternative income generation holds second rank. In support of this statement a key informant with ID No./code NSNP2 clarifies as follows.

"The primary driving force for the deforestation of the Arba Minch Forest is lack of alternative income generation for the poor local community. Hence, they are forced to experience deforestation for firewood, charcoal, construction materials, food provisioning services, etc. However, there are also peoples who are coming from the neighbor rural areas and even from the far neighbor towns, who have been practicing deforestation for the commercial purposes."

The other reasons or driving forces for the deforestation are the increasing demand of Arba Minch town residents and surrounding local communities for energy sources (firewood and charcoal). Likewise, about $143(15.70 \%)$ and 134 (14.71\%) respondents gave responses on that peoples experiencing deforestation for firewood and charcoal energy sources respectively. Nevertheless, peoples have been experiencing deforestation not only for their household consumption, but also for commercial purposes. About 131 $(14.38 \%)$ and 136 (14.93\%) household respondents pointed that peoples have been experiencing deforestation for energy sources (firewood and charcoal) for household consumption and commercial purposes.

Likewise, Arba Minch town residents and local communities are dependent on the Arba Minch Forest ecosystem for the construction materials as well as for the food provisioning services (fruits, flowers, wild honey, mushrooms and wild game/fish). As a result, they have been experiencing deforestation to get these services.

On the other hand, peoples experiencing deforestation in the Arba Minch Forest ecosystem for the agricultural expansion is insignificant. This is shown in that, there are only $9(0.99 \%)$ household respondents are selected that the driving force for the deforestation of the Arba Minch Forest ecosystem is with the aim of agricultural expansion. This is seldom activity which is practiced around the area so called "Chamo Leto" that some local communities and investors have been trying to deforest for the expansion of their agricultural farm which has been inapplicable for several times (figure 2).

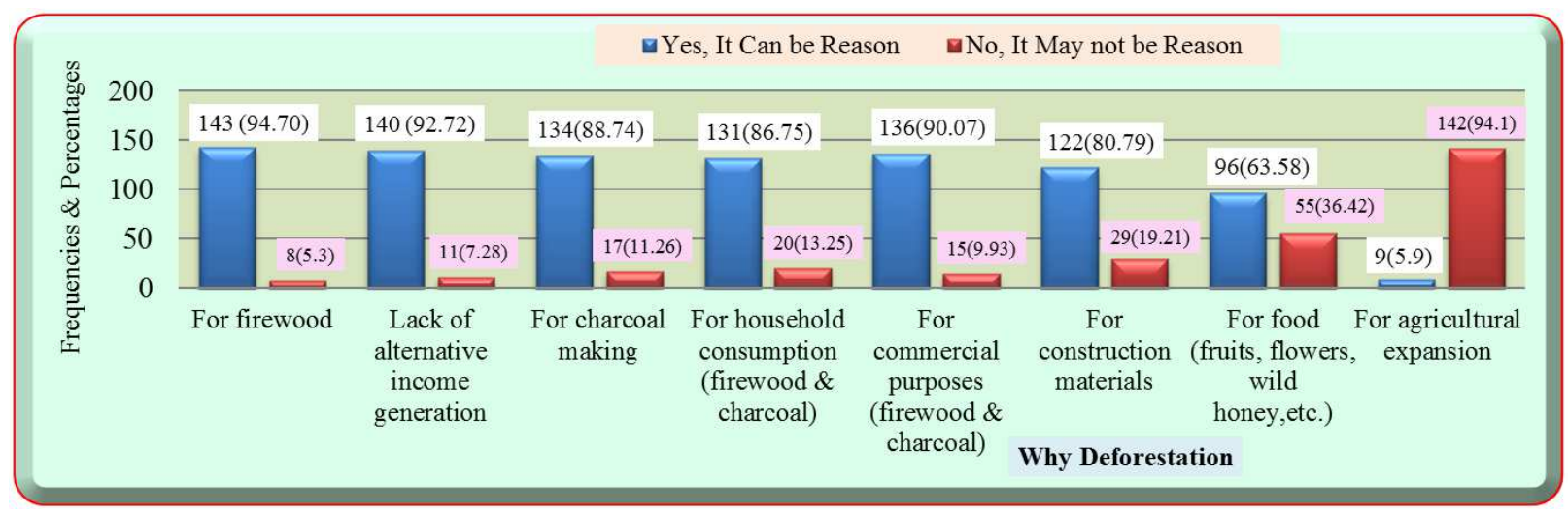

Source: Field Survey (2017/18)

Figure 2. Respondents'Perception for the Reasons of Deforestation. 


\subsubsection{Lack of Alternative Livelihood Generation for the Poor Local Communities}

Due to lack of alternative livelihood generation, most of the Arba Minch town poor residents have been experiencing deforestation to sustain their survival. According to respondents report most of the Arba Minch town poor residents have been ensuring their daily consumption, teaching their children, meeting their different expenditures, etc. through gathering different provisioning services (firewood, charcoal, etc.) from the Arba Minch Forest ecosystem. Besides to the Arba Minch town poor residents, there are also wood cutters who are coming from the Arba Minch town surrounding kebeles inhabitants and neighbor rural areas like the so called "Zigiti", "Dita", "Kole", "Balta", "Kamba", "Dermalo", etc. Those peoples who are coming from the surrounding kebeles and from far rural areas have been also practicing deforestation due to lack of alternative livelihood generation. They are renting the house for some period of months in Arba Minch town and practicing deforestation mostly for commercial purposes. In support of this explanation a key informant with ID No./code NSNP2 describes as under.

"There are also peoples who are coming from the neighbor rural areas and even from the far neighbor towns, who have been practicing deforestation in the Arba Minch Forest ecosystem for the commercial purposes."

On the other hand, among the 21 peoples interviewed who are entering into the Arba Minch Forest ecosystem, expressed that peoples are gathering provisioning services (firewood, charcoal, food, construction materials, etc.) for different purposes. About $12(57.14 \%)$ respondents explained that peoples are gathering provisioning services for both household and commercial purposes, while 5 (23.81\%) and 4 (19.05\%) respondents were pointed out that peoples are gathering provisioning services for household consumption and commercial purposes only. Peoples those coming from the Arba Minch town surrounding kebeles inhabitants and neighbor rural areas are gathering provisioning services mainly for the commercial purposes. They supply energy sources (firewood and charcoal) for their customers (households and accommodations delivers, etc.), and sell in the market. Arba Minch town poor residents are also sell the energy sources (firewood and charcoal) in the market to ensure their survival.

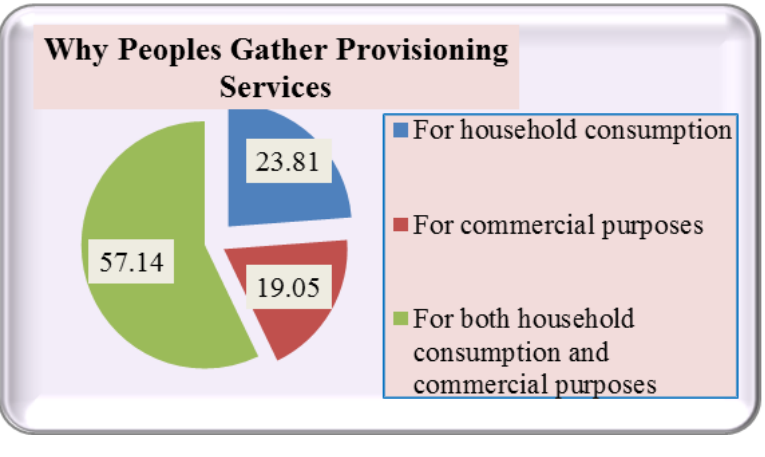

Source: Field Survey (2017/18)

Figure 3. Why peoples gather provisioning services from the Arba Minch Forest.
Likewise, among 21 peoples interviewed who are entering into the Arba Minch Forest ecosystem, about 19 (35.16\%) are responded that they are entering into the Arba Minch Forest ecosystem to gather firewood provisioning services; at the same time, among them $16(29.63 \%)$ are also entering into the Arba Minch Forest ecosystem to make charcoal and to collect food provisioning services. This shows that, the same individual may enter three or four times per a day either to gather firewood, to make charcoal or to collect food provisioning services. In contrast, about 8 (14.81\%) peoples responded that they have been entering into the Arba Minch Forest ecosystem to experience ecotourism and recreation. Most of the peoples who have been experiencing ecotourism and recreation are university and high school students, conservation clubs members and youngsters.

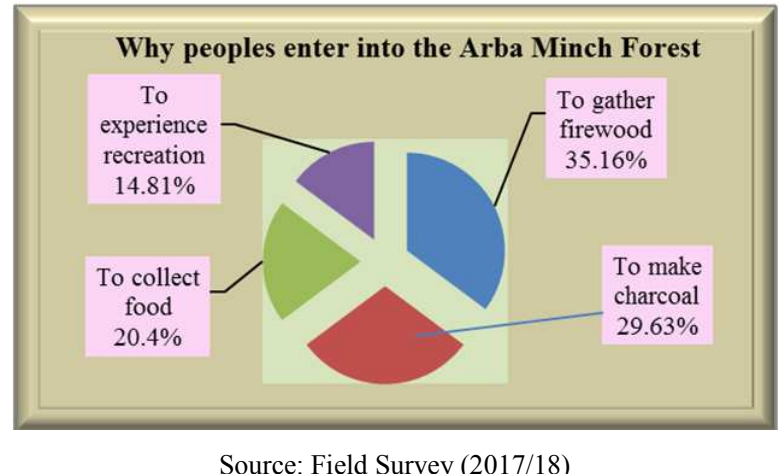

Figure 4. Why peoples enter into the Arba Minch Forest.

\subsubsection{Dependence of the Households and Services or Accommodations Delivers on the Arba Minch Forest as Energy Sources}

The whole Arba Minch town residents and surrounding local communities are dependent up on the Arba Minch Forest ecosystem for their energy sources including households, accommodation, delivers, big institutions, etc. About $96.36 \%$ have been using firewood and charcoal as energy sources. They get these energy sources either purchasing firewood and charcoal from the market, woodcutters bring firewood and charcoal to home or directly self-collecting firewood and charcoal from the Arba Minch Forest ecosystem. Accordingly, about $72.18 \%$ of household respondents are getting their energy sources through purchasing firewood and charcoal from the market and woodcutters bring to home. On the other hand, about $23.18 \%$ of the household respondents are obtaining their energy sources (firewood and charcoal) through directly selfcollecting from the Arba Minch Forest ecosystem. In contrast, only $4.63 \%$ of the household respondents are using electricity as their energy sources. Nevertheless, they are not only using electricity but also they are using firewood and charcoal as their energy sources as well.

Correspondingly, services/accommodations deliver (hotels, lodges and restaurants) and big institutions are also consuming firewood and charcoal as energy sources. Among the 9 sampled accommodations delivers, about $6(66.67 \%)$ are 
consuming firewood and charcoal for their energy sources while only $3(33.33 \%)$ are using electricity. About $6(66.67 \%)$ of accommodation delivers are getting their energy sources (firewood and charcoal) through directly purchasing from the market and informal suppliers (woodcutters bring directly to their home). Accommodations delivers are not directly engaged in self-collecting firewood and charcoal from the Arba Minch Forest ecosystem. However, peoples those engaged in deforestation for the commercial purposes are informally supplying energy sources (firewood and charcoal) for the interested accommodation delivers and even for the households. sources (firewood and charcoal) for the interested accommodation delivers and even for the households.

\subsubsection{Weak Contribution from the Stakeholders for the Conservation Activities}

All human beings living in the Arba Minch town are dependent up on the ecosystem services of the Arba Minch Forest ecosystem. The secret of the presence of the all accommodations delivers (hotels, lodges, restaurants, pensions, internet cafes, supermarkets, transportation provides, etc) is that the presence of the Arba Minch Forest ecosystem. The presence and business of ecotourism associations (local tour guide, boat service, recreational, beekeeping, etc.) and non-ecotourism associations like fishermen associations is due to the presence of the Arba Minch Forest ecosystem. If there is no Arba Minch Forest ecosystem, there is no such businesses of the accommodation delivers, ecotourism and non-ecotourism associations since all their customers or visitors (international and domestic) are coming to Arba Minch and using their services is due to the presence of the Arba Minch Forest ecosystem. Hence, this forest delivers all ecosystem services (provisioning, regulatory, cultural and habitat) to the progenies of mankind as well as wild fauna and flora.

In the same way, governmental and non-governmental institutions, governmental and private higher institutions (colleges and universities), all Arba Minch town residents, etc. are dependent up on the Arba Minch Forest ecosystem services. Since, it is "lung" for the Arba Minch town which exhales fresh air to the town; and inhales urban suffocation and wastes. The above statements get strong support from a key informant with ID No. /code NSNP3 as stated under.

"Visitors' services/accommodations delivers (hotels, lodges, restaurants, internet cafes, transportation providers, etc.) ecotourism associations (boat service association, local tour guide association, beekeeping, fishermen association, etc.), higher institutions (colleges and universities), governmental and non-governmental institutions, all Arba Minch town residents, etc. are dependent on the ecosystem services of the Arba Minch Forest. In spite of their some contribution for the conservation activities, it is insignificant to ensure the sustainability of the Arba Minch Forest."

Hence, for the sake of the described ecosystem services of the Arba Minch Forest ecosystem, stakeholders have been trying to ensure sustainable conservation through collaborating and giving certain contributions for the conservation activities. They have been trying to teach local communities in different programmes, participating in meetings, workshops, panel discussions, etc. regarding the issues of the Arba Minch Forest ecosystem conservation, they have been raising constructive ides for the conservation, collaborating to control illegal activities (illegal fishing, wild fire, etc.), even some stakeholders providing material support like car for some period of time for the conservation activities, etc.

In spite of the elaborated conservation activities of the stakeholders, their contribution, collaboration and commitment for the sustainable conservation of the Arba Minch Forest ecosystem is insignificant. If their contribution, collaboration and commitment for the sustainable conservation have been significant, the ongoing and intensifying challenges on the Arba Minch Forest ecosystem had been stopped or minimized. But, conservation constraints like deforestation for firewood and charcoal has been intensifying from time to time. Business sectors have been generating their profit or running to maximize their profit as well as governmental and non-governmental institutions have been engaged/concentrated on the other developmental projects like infrastructure, health care, education, food security, etc. This all business and developmental projects may face obstacles in near future, if Nech Sar National Park administration, all concerned stakeholders and governmental and non-governmental institutions fail to ensure sustainable conservation of the Arba Minch Forest ecosystem. Because, Arba Minch Forest ecosystem is fundamental for the economic prosperity, social health and development, ecological health, etc. for the Arba Minch town, local areas as well as for the national level.

\subsubsection{Weak Enforcement of Policy, Proclamations, Regulatory Measures and its Compliance}

According to [16] policy and strategy, Ethiopia is endowed with several valuable wildlife and natural resources. These have a great potential in enhancing the country's development efforts. However, the country has not realized the potential economic benefits from the sector. The main threats to the country's wildlife resources result from improper land use, which includes habitat destruction. Accordingly, it has become essential to produce viable policies and strategies to protect and develop properly the country's wildlife resources, conserve the endemic wildlife and the natural resources for posterity, support the country's economy. The major objective of the policy is to create conducive environment whereby the country's wildlife and their habitats are protected and developed in a sustainable manner, and to enable the sector to play an important role in the economic development of the country.

In line with this, the study [17] describes the prohibited activities in National Parks, Wildlife Sanctuaries, and Wildlife Reserves under article 5. Under article 5, sub-article 1 states that no person shall carry out any of the following activities: Sub-article (1b) hunting or fishing; (1d) picking, 
disturbing, destroying, damaging or defacing any natural or manmade object;(1i) planting, cutting, chopping, removing, taking, damaging or transferring any plat species; $(1 \mathrm{j})$ setting or attempting to set fire.

Likewise, the study [18] explains about penalty under article 16. Under article 16, sub-article 1 states that unless it entails higher penalty under the criminal law: a) any person who: (i) commits an act of illegal wildlife hunting or trade; (ii) carries out unauthorized activities within wildlife conservation areas or causes, in whatever way, damage thereto; or (iii) is found in possession of wildlife or wildlife products without having a permit; shall be punished with fine not less than Birr 5000 and not exceeding Birr 30,000 or with imprisonment not less than one year and not exceeding five years or with both such fine and imprisonment. (b) any person who commits other offences in violation of the provisions of this proclamation or regulations or directives issued hereunder shall be punished with fine not less than Ethiopian Birr 500 and not exceeding Birr 3,000 or with imprisonment not less than one month and not exceeding six months or with both such fine and imprisonment.

In line with the stated policy, proclamation, regulatory measures and penalty procedures, Nech Sar National Park management with the committed stakeholders have been working to implement the policies, strategies, proclamations, regulations, penalty procedures as well as to tackle illegal activities like prohibited activities (fishing, setting unintentional fire, wildlife poaching, deforestation, etc.).

Nevertheless, in most cases peoples those participated in prohibited activities (illegal activities) have been setting free despite the stated policies, proclamations and regulations of the EWCA. This is due to either lack of awareness and clear understanding of the ecosystem services of the Arba Minch Forest, reluctance or immoral activities of the concerned law enforcing bodies. The other weakness in implementing the regulator measures is the limited capacity of the NSNP administration like inadequate awareness creation of the local community, insufficient budget, poor infrastructure within the Park, and shortage as well as poor field facilities for the conservation activities. A key informant with ID No./code NSNP2 gave emphasis as follows.

"The working policy, proclamation, regulations and compliance procedures of the Ethiopian Wildlife Conservation Authority (EWCA) are sufficient enough for the conservation of the Arba Minch Forest. Nevertheless, the enforcement and implementation of the regulations and compliance procedures on the ground is limited due to lack of awareness of the local community, lack of strong commitment of the concerned stakeholders, inadequate budget, poor infrastructure within the Park, and insufficient as well as poor field facilities for the conservation activities."

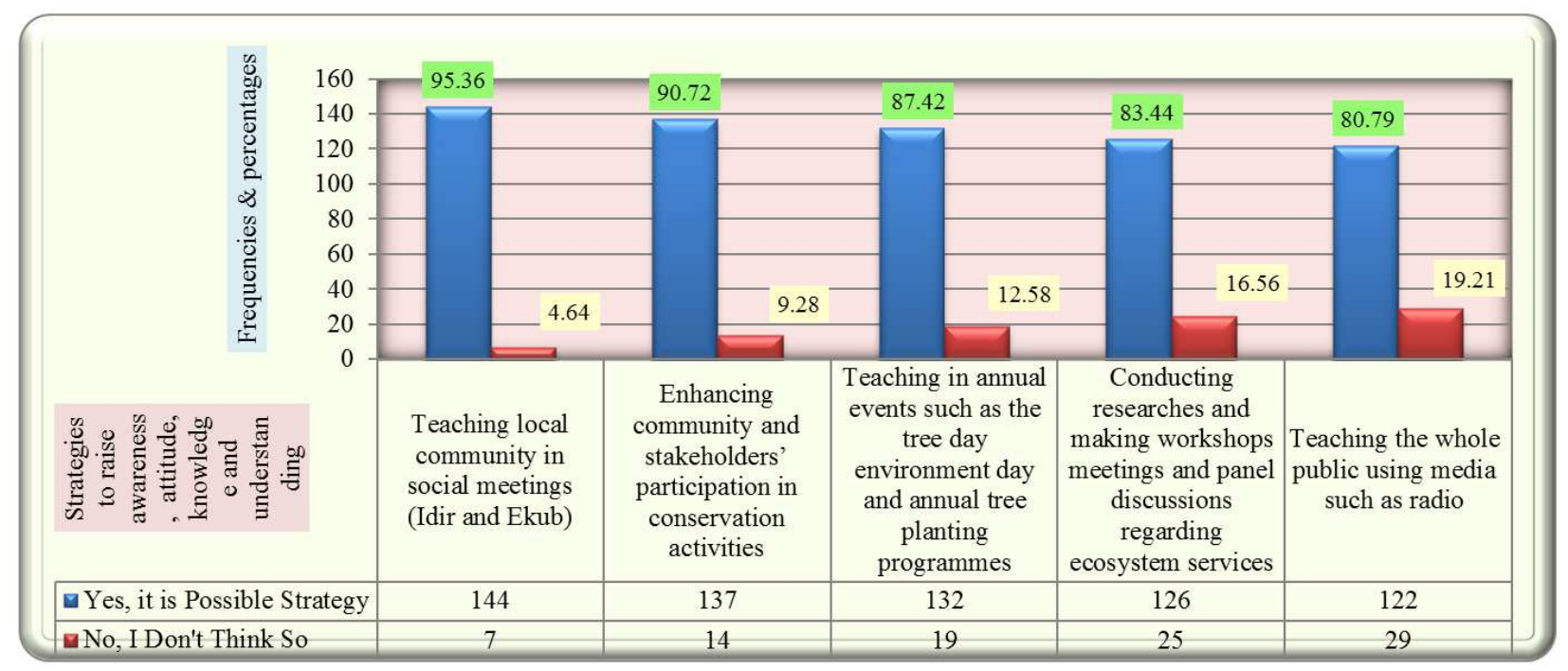

Source: Field Survey (2017/18)

Figure 5. Respondents' perception how to raise awareness, attitude, knowledge and understanding regarding the values and ecosystem services of the Arba Minch Forest.

\subsection{Potential Conservation Strategies}

\subsubsection{Enhancing Public Awareness and Understanding About the Values and Ecosystem Services}

Household respondents pointed out different strategies how to raise awareness, attitude, understanding and knowledge regarding the values and ecosystem services of the Arba Minch Forest ecosystem. According to about 144 (21.78\%) household respondents' perception, the first stage to raise the awareness, attitude, understanding and knowledge regarding the ecosystem services of the Arba Minch Forest ecosystem is teaching local communities for some minutes in local social meetings (Idir, Ekub). Again, about 137 (20.73\%) respondents emphasized enhancing community and stakeholders' participation in conservation activities. As their perception, if the local community and stakeholders participate in every conservation activities, first of all, they may raise their awareness and understanding about ecosystem services; secondly, they become informed 
about the ongoing challenges of the Arba Minch Forest ecosystem and its consequences; thirdly, they may develop the sense of ownership when their participation level is increasing and lastly they may give recognition, value and develop commitment for the conservation activities. The other strategy to raise awareness, attitude, understanding and knowledge concerning the ecosystem services of the Arba Minch Forest ecosystem is teaching local communities in annual events such as tree days, world forestry days, tree planting programmes, environmental days, etc. About 132 (19.97\%) household respondents gave weight to this statement. Hence, such annual events are a good opportunities to raise awareness of the large community within short period of time with minimum costs through distributing brochures, booklets, flyers, slogans, etc. Likewise, $126(20.62 \%)$ household respondents are in favor of conducting scientific researches, making workshops, meetings, panel discussions, etc. as the other options to raise awareness, attitude, understanding and knowledge regarding the values and ecosystem services of the Arba Minch Forest ecosystem. About 122 (18.46\%) household respondents support other strategy like developing promotion, teaching the whole public about the results of the scientific researches, making interview with experts, etc. and transmitting all issues to the public using radios are also the crucial strategy to raise awareness, attitude, understanding and knowledge regarding the ecosystem services of the Arba Minch Forest ecosystem. Besides, a key informant with ID No./code NSNP2 agrees with this statement in saying that:

"Since Arba Minch Forest is "backbone" for the existence of the Arba Minch town, every mankind should teach one another, speak and share ideas, etc. about its ecosystem services in every event like tree days, World forestry days, tree planting programmes, environmental days, panel discussions, meetings, workshops, etc."

\subsubsection{Enhancing Stakeholders' Participation, Recognition and Coordination}

Acting alone, neither communities nor stakeholders nor Nech Sar National Park administration enhances in a position to successfully manage multiple services of Arba Minch Forest ecosystem. Combining the strengths of different players through active participation is a rational response to the conservation constraints of the Arba Minch Forest ecosystem. The word active participation implies how and to what extent people are able to share their views, take part in an activity, project, programme, decision making, profit sharing and other issues related the sustainable conservation. If local people, stakeholders and decision makers are not involved in every aspect of conservation activities and if they lack sense of ownership, it is likely to be over time, the Arba Minch Forest ecosystem on which all human beings depends will be destroyed and the overall ecological, social and economic investment will be lost. Indigenous community and stakeholders, with their traditional knowledge systems, can contribute immensely to the conservation of Arba Minch Forest that would help to curtail the adverse effects of current challenges like deforestation. Hence, for successful conservation of the Arba Minch Forest ecosystem; active participation, recognition and coordination among all stakeholders, local community and Nech Sar National Park administration are pivotal.

\subsubsection{Recruiting Sufficient Human Resource and Capacity Building}

According to the human resource department of the NSNP (2017) in general, about $31.97 \%$ is vacant positions of the Nech Sar National Park human resource which need urgent recruitment of human resource for sustainable conservation of the Arba Minch Forest ecosystem. According to the key informant ID No./code NSNP3, the issue is not only recruiting human resource in vacant positions of the respective core processors but also building the capacity of the existing as well as new employees for better conservation.

"Besides to the inadequate human resource for the conservation activities, it needs capacity building in education level, knowledge and skill for the conservation activities. For experts, training and education in skills of monitoring, wildlife census techniques, fauna and flora identification, how to use field equipments and technology (GPS, compass, GIS, etc.), research methods, project planning, etc. while for scouts/rangers, upgrading their education level for the monitoring and conservation activities."

\subsubsection{Strengthening Investment in Training, Education and Research Activities}

On the behalf of the Nech Sar National Park management, enormous awareness creation and discussions workshops, panel discussions, promotions, etc. with local communities, conservation clubs, stakeholders, ecotourism associations, etc. has been done to ensure sustainable conservation of the Arba Minch Forest ecosystem.

Despite these enormous conservation activities, Arba Minch Forest ecosystem is continued to be destroyed. Insignificant education, training, awareness creation, discussions, workshops, panel discussions, promotions, etc. are among the reasons of the ongoing challenges of the Arba Minch Forest ecosystem. Hence, strengthening significant training and education, awareness creation and discussions, workshops and panel discussions, etc. for the local communities, stakeholders, NSNP personnel, conservation clubs, ecotourism associations, etc. concerning the Arba Minch Forest ecosystem is one of the vital activities to ensure sustainable conservation of Forest ecosystem.

In addition to this, as secondary data sources shows from the Nech Sar National Park office, there have been different researches (master thesis and PHD dissertations) conducted in the NSNP like Protected area management, local livelihoods and resource use conflicts in the case of Nech Sar National Park, Ethiopia, The ecology of the major Ethiopian rift valley lakes Abaya and Chamo with special reference to food web structure and water quality, Determinants of land cover dynamics in Nech Sar National Park South Ethiopia 
Rift valley, Understanding ecological interaction among ungulates small mammals and vegetation in savannah grassland Nech Sar National Park, South Ethiopia Rift valley, etc. In the same way, Abiyot (2009) conducted research on Resettlement and Local Livelihoods in Nechsar National Park, Southern Ethiopia; Sintayehu, Afework and Mundanthra (2011) Species Diversity and Abundance of Small Mammls in Nechisar National Park, Ethiopia; Aramide et al. (2014) Study of Changes in Habitat Type Distribution and Habitat Structure of Nech Sar National Park, Ethiopia; Samson, Tamirat and Alemayehu (2010) Floristic Diversity and Structure of Nechisar National Park, Ethiopia, etc.

On the other hand, limited studies have been carried out regarding conservation constraints and strategies of the Arba Minch Forest ecosystem. It is one reason for the lack of awareness and clear understanding of the values and ecosystem services of the Arba Minch Forest ecosystem, lack of recognition, coordination and commitment among stakeholders, challenges escalating, etc. Therefore, enhancing investment in research activities on the subject of ecosystem services, constraints and potential conservation strategies, community participation, valuation of the ecosystem services, quantification of the ecosystem services, etc. of the Arba Minch Forest ecosystem is principal issue.

Respondents' Perception to What Alternative Income Opportunities Should be Created for the Poor Local Community

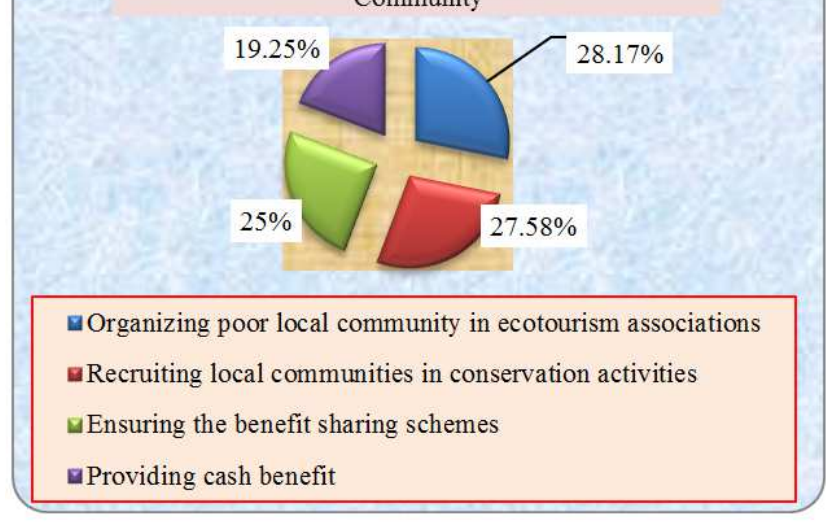

Source: Field Survey $(2017 / 18)$

Figure 6. Respondents' perception to what alternative income opportunities should be created for the poor local community.

\subsubsection{Creating Alternative Livelihood Generation for the Poor Local Communities}

Household respondents pointed out some alternative livelihood opportunities for the poor local communities in order to ensure sustainable conservation of the Arba Minch Forest ecosystem. About 142 (28.17\%) respondents are on the behalf of organizing poor local communities in ecotourism associations (beekeeping, boat service, recreational centers, local tour guide, etc.) while about 139 $(27.58 \%)$ respondents are in favor of recruiting local communities in conservation activities as employees in order to maximize community participation and sense of ownership. The other alternative opportunity to ensure sustainable conservation is that ensuring the benefit sharing schemes. This is supported by about $126(25 \%)$ respondents. They pointed out that the presence of the Nech Sar National Park should sustain the benefit sharing schemes for the local community. This can be done through providing different public services like building schools, health centers, recreational places, etc. creating job opportunity for the local educated youths, providing working sites for the ecotourism associations, supporting young ecotourism associations through advising, monitoring and material support and so on. Even though it is not advisable, some respondents about 97 $(19.25 \%)$ indicated that providing cash benefit for the poor local communities is the other alternative livelihood opportunities. There may be direct cash payment for the daily laborers who may work in different conservation activities within the park like infrastructures development, campsite building, clearing invasive species, controlling illegal activities, etc. But, direct provision of the cash benefit for the local community to make sense of ownership is inappropriate.

Key informants also support the household respondents' view of alternative livelihood opportunities to the poor local community. They gave emphasis on alternative livelihood opportunities like organizing poor local communities in ecotourism associations, recruiting local communities in conservation activities as employees and ensuring benefit sharing schemes. Besides, they underline the issue of identifying Arba Minch town dwellers those who have no alternative livelihood generation before organizing them in different ecotourism associations. Key informants are less interested in direct provision of cash benefit to the poor local communities, rather they believe in direct payment for professional works like writing different promotion works, printing brochures and flyers, different designs and works of artists, etc. Besides, they agree with direct cash payment for laborers those participated in different activities within the Park like infrastructures development, campsite building, clearing invasive species, controlling illegal activities, etc. this explanation is stated by a key informant with ID No./code NSNP3 as follows.

"First of all, identifying peoples those who have no alternative livelihood income generation, then, organizing them in ecotourism associations (local tour guiding, boat service, beekeeping, recreational centers, cultural dressings and artifacts, etc.) and recruiting local communities in conservation activities as employees to ensure benefits and values of the presence of the Nech Sar National Park and to create sense of ownership among all stakeholders as well as local communities."

\subsubsection{Ensuring Alternative Energy Sources of Households, Accommodations Delivers and Institutions}

As already explained, almost all households (96.36\%) and accommodations delivers (66.67\%) have been consuming firewood and charcoal as energy sources which are from the Arba Minch Forest ecosystem. Besides, public and private institutions also are getting and consuming energy sources in 
same manner. So, ensuring alternative energy sources of households, accommodations delivers, public and private institutions, etc. is not a choice; it is a matter of existence of Arba Minch town. Strong emphasis was given by a key informant with ID No./code AD7 as follows.

"We have to sustain the conservation of the Arba Minch Forest ecosystem, minimize our dependence on the firewood and charcoal as energy sources and ensure alternative energy sources consumption for the sake of our existence and coming generations."

The ecosystems services of the Arba Minch Forest ecosystem look like surplus and endless. If the current challenges particularly deforestation for the sake of the energy sources and to ensure livelihood to be continued, in near future the Arba Minch Forest ecosystem will be destroyed. If so, no more ecosystems services (provisioning, regulatory, habitat and cultural) of the Arba Minch Forest ecosystem will exist. As a result, the life in Arba Minch town will be in dilemma. Therefore, minimizing the dependence on the Ground Water Forest ecosystem for the energy sources and ensuring alternative energy sources like electricity, biogas, etc. is the primary homework and should get priority among all concerned stakeholders, public sectors, private sectors, non-governmental organizations, associations, business centers, Nech Sar National Park management, etc.

\subsubsection{Generating Significant Contribution from Stakeholders for Sustainable Conservation}

Since Arba Minch Forest ecosystem is basic entity for the survival of all dwellers of Arba Minch town, accommodations delivers, ecotourism associations, governmental and non-governmental institutions, etc. it needs the collaboration, recognition, commitment, contribution, etc. of all concerned stakeholders to sustain their survival as well as ecosystem services of the Arba Minch Forest ecosystem. Accordingly, among the 9 accommodations delivers interviewed, in frequency about $33.33 \%$ are in favor of supporting to organize poor local community in ecotourism associations (beekeeping, local tour guide, recreational centers, boat service, etc.), $28.57 \%$ are interested in supporting already organized young ecotourism associations, $23.81 \%$ are in favor of providing material support like car, boat, etc. for the conservation activities and $14.28 \%$ are giving certain percent of their income for the conservation activities.

Key informants also have similar opinion with the accommodations delivers observation regarding ways of significant contribution for the sustainable conservation of the Arba Minch Forest ecosystem. They underline all the stated ways of contribution as possible strategies to generate significant contribution from all stakeholders. They ensures that for sustainable conservation of the Arba Minch Forest ecosystem, every humankind either, educated or illiterate, merchant or business man, teacher or students, etc. should stand together. A key informant with ID No./code EAL2 gives stresses as under.

"Conservation of the Arba Minch Forest ecosystem is not the concern of a single entity; it is an issue of every man kind and needs participation, collaboration, contribution, recognition, valuation, commitment, etc. of all concerned stakeholders including a single individual."

The other key informant with ID No./code AD4 indicates that the non-financial support for the conservation activities also has significant contribution.

"Arba Minch Forest ecosystem conservation requires not only the financial support, but also it needs material support, labor provision, raising constructive ideas, recognition, commitment, etc. of every individual that it has significant contribution for the sustainable conservation."

\subsubsection{Strengthening Enforcement of Policy, Proclamations, Regulatory Measures and Its Compliance}

To realize the potential socio-economic benefits through utilizing ecosystem services of the Arba Minch Forest sustainably, strengthening the enforcement and implementation of the Ethiopian Wildlife Conservation Authority policy, proclamation, regulatory measures and its compliance is crucial. According to the study [16] concerning the policy of training and education, under article 4, sub-articles $4.2 \mathrm{~A}$ and $4.2 \mathrm{C}$, the strategies states that organizing educational programs to raise public awareness on the socio- economic importance of wildlife resources and to enable community contribute to conservation; and educating the community about the damage that could be caused by wildlife and the necessary measures to be taken to reduce the problems is crucial activity respectively. According to the study [17] prohibited activities in National Parks under article 5 are (hunting or fishing picking, disturbing, destroying, damaging or defacing any natural object, planting, cutting, chopping, removing, taking, damaging or transferring any plat species, setting or attempting to set fire, etc. So, strengthening awareness creation, education, training, etc. of the local communities, law enforcing bodies, stakeholders, etc. concerning the policy, proclamations, regulatory measures, directives, prohibited activities in National Parks, etc. as well as socio- economic importance of wildlife resources, ecosystem services, etc. is central issue.

Likewise, under article 2, sub-articles 2.4B creating job opportunities for communities residing around protected areas is one strategy to implement the policy concerning income secured from wildlife resources will be used to benefit local people, wildlife conservation endeavors, as well as for the overall growth of the national economy. Hence, following awareness creation, education training etc., creating job opportunities and alternative livelihood generation for communities residing around the national parks is significant activity.

On the other hand, the study [18] describes about penalty under article 16. Under article 16, sub-article 1 states that unless it entails higher penalty under the criminal law: a) any person who: (i) commits an act of illegal wildlife hunting or trade; (ii) carries out unauthorized activities within wildlife conservation areas or causes, in whatever way, damage 
thereto; or (iii) is found in possession of wildlife or wildlife products without having a permit; shall be punished with fine not less than Ethiopian Birr 5000 and not exceeding Ethiopian Birr 30,000 or with imprisonment not less than one year and not exceeding five years or with both such fine and imprisonment. (b) any person who commits other offences in violation of the provisions of this proclamation or regulations or directives issued hereunder shall be punished with fine not less than Ethiopian Birr 500 and not exceeding Ethiopian Birr 3,000 or with imprisonment not less than one month and not exceeding six months or with both such fine and imprisonment.

Therefore, next to awareness creation, education, training, creating alternative livelihood generation, etc. enforcing and implementing the policy, proclamations, regulatory measures, directives, etc. on the ground is vital activity to sustain the flow of the ecosystem services, to fix the challenges and to enhance conservation of the Arba Minch Forest ecosystem. Ensuring adequate budget and improving infrastructure within the Park is also essential for the enforcement and implementation of the regulatory measures. A key informant with ID No./code NSNP2 gave emphasis on this issues as under.

"The working policy, proclamation, regulation and compliance procedures of Ethiopian Wildlife Conservation Authority (EWCA) should be enforced and implemented on the ground through raising awareness of the local community, ensuring commitment among concerned stakeholders, ensuring adequate budget, improving infrastructure within the Park, and ensuring sufficient and working field facilities for the conservation."

\section{Conclusion}

Human beings are utterly dependent on nature particularly on the forest ecosystem services. Our health, economy, prosperity, development and security are all connected to the forest ecosystem services. Healthy and conserved forest ecosystems supply us with food, freshwater, clean air, and a stable climate. Arba Minch Forest ecosystem is a fundamental entity for the continuation and survival of the Arba Minch town and dwellers inside it, and its vicinities. The whole Arba Minch town dwellers and its environs are dependent on the ecosystem services of the Arba Minch Forest ecosystem. It provides all ecosystem services to the Arba Minch town and its vicinities (provisioning, regulatory, cultural and habitat services). It delivers provisioning services like firewood, charcoal, water, food, construction materials, etc. It also offers regulatory services including maintenance of fresh air and local weather conditioning, flood control and water overflow prevention, purification of the forty springs, waste assimilation, etc. It maintains local weather conditioning and climatic conditions and serves as a "lung" for the Arba Minch town through releasing fresh oxygen to the whole Arba Minch town and absorbing urban carbon dioxides. It can be termed as "absorber" of all urban wastes (solid and liquid) which are going to affect aquatic lives of Kulfo River and Chamo Lake. It plays significant role in purifying forty springs via absorbing all wastes by the leaves and roots of huge trees and preventing soil erosion and sediments which are entering into the forty springs. Concerning cultural services, this forest ecosystem also affords spiritual and mental satisfaction and recreation, enhances inspiration for culture, art and design, home for variety of fauna and flora species, and adds cultural and aesthetic value. It is wonderful visitors' attraction site which holds various ecotourism and recreational opportunity like mountain climbing, trekking, bird and animal watching, forest walking, swimming in the pond, etc. It also renews, refreshes, provides mental and spiritual satisfaction for the visitors.

In spite of its undeniable and worthy ecosystem services, due to anthropogenic activities, Arba Minch Forest ecosystem is under inevitable pressures particularly from the residents of the Arba Minch town and its environs. Lack of awareness, clear understanding, collaboration, recognition, commitment, etc. of the local communities, concerned stakeholders and decision makers are the major factors which exacerbates the ongoing challenges. The increasing demand for energy sources and dependence of the Arba Minch town residents, accommodations delivers, big institutions, etc. on the Arba Minch Forest ecosystem enhances deforestation which deteriorates ecosystem services largely. Besides, lack of the alternative livelihood generation of the poor local communities is the major driving force for the deforestation. If the ongoing challenges to be continued, the life and survival in Arba Minch town is in question.

Hence, putting into practice the recognized potential conservation strategies on the ground is the key opportunity to save the Arba Minch Forest ecosystem and sustain its ecosystem services for the progenies of the mankind as well as wild fauna and flora. In addition to awareness creation, education, training, conducting scientific researches, etc., putting into the practice the identified alternative livelihood generation for the poor local communities is ideal strategy to halt deforestation. Ensuring alternative energy sources (electricity, solar energy, biogas, etc.) of the households, accommodations delivers, big institutions, etc., is vital strategy. The other potential strategy could be generating significant contribution for the conservation activities from all concerned stakeholders, direct and indirect beneficiaries of the Arba Minch Forest ecosystem. Moreover, recruiting adequate human resource and building capacity for the conservation activities is crucial strategy. After all, enforcing and putting into the practice on the ground the written policy, proclamation, regulatory measures, directives, etc. for the sustainable conservation of the Arba Minch Forest ecosystem.

\section{Recommendations}

Recommendations for Practice

For EWCA and NSNP office: 
1) Strengthening the public awareness, education, training, discussions, etc. to raise the knowledge base and give a clear understanding of the values and ecosystems services of the Arba Minch Forest.

2) Mobilizing stakeholders for the coordination, collaboration and commitment for the conservation activities of the Arba Minch Forest ecosystem.

3) Recruiting adequate human resource in vacant positions and enhancing capacity building of the staff personnel.

4) Putting into practice the identified alternative livelihood generation opportunities for the poor local communities in order to halt deforestation

5) Strengthening the enforcement and implementation of the working policy, proclamations, regulatory, etc. with the collaboration of the concerned stakeholders.

For All Stakeholders and Decision makers:

1) Enhancing the works of awareness creation, education, discussions, etc. to raise the awareness and understanding of public in different methods like annual events, using Radios and Medias, etc.

2) Giving due attention, collaboration, recognition, valuation and commitment for the conservation of the Arba Minch Forest ecosystem.

3) Encouraging students and researchers to carry out study on the issues of the Arba Minch Forest ecosystem.

4) Ensuring alternative energy sources (electricity, solar energy, biogas, etc.) for the Arba Minch town residents, accommodations delivers, public and private institutions, etc.

5) Securing alternative livelihood generation opportunities for the poor local communities in order to halt deforestation and strengthening significant contributions for the conservation activities.

6) Enhancing the enforcement and implementation of the working policy, proclamations, regulatory, etc. through the common understanding and consensus with the collaboration of the concerned stakeholders.

Recommendations for the Further Study

1) Conducting deep and more scientific researches on each ecosystem services categories separately (provisioning, regulatory, cultural and habitat services) of the Arba Minch Forest ecosystem is crucial.

2) Carrying out researches on the Quantification of the each ecosystem services of the Arba Minch Forest ecosystem.

3) Conducting researches on the Willingness to pay of the Local Communities for the sustainable conservation of the Arba Minch Forest ecosystem.

4) Conducting researches on the Total Economic Value of the ecosystem services of the Arba Minch Forest ecosystem for sustainable conservation.

\section{Acknowledgements}

First and foremost, we would like to give thanks from our full heart to our almighty God who helped us through obstacles to till today, and will be with us in future. All the people involved in the interview and discussions are duly acknowledged. We are thankful to our field assistants for their help in data collection.

\section{References}

[1] Food and Agricultural Organization of the United Nations (FAO) (2010). Global Forest Resources Assessment. FAO Forestry Paper 163. Rome, Italy.

[2] Chavan SP (2013). Role of Joint Forest Management Committees in the Conservation of Forest and Environment. Indian Streams Research Journal, Vol. 3 (6).

[3] Haines-Young RH and Potschin MB (2011): Common International Classification of Ecosystem Services: 2011 update. Centre for Environmental Management, University of Nottingham, UK.

[4] Jodi N, Allan P, Helen J, Ece O, Jaboury G, Diane B and Kerry T (2005). TheEconomic, Social and Ecological Value of Ecosystem Services A Literature Review. Final report for Department for Environment, Food and Rural Affairs. London.

[5] Millennium Ecosystem Assessment (MEA) (2007). A Toolkit for Understanding and Action. Washington, DC, USA: Island Press.

[6] Muhumuza M and Balkwill K (2013). Factors Affecting the Success of Conserving Biodiversity in National Parks: A Review of Case Studies from Africa. International Journal of Biodiversity, Hindawi Publishing Corporation.

[7] Sintayehu W, Afework B and Mundanthra B (2011). Species Diversity and Abundance of Small Mammals in Nechisar National Park, Ethiopia. Ecologia, 50: pp. 102-108.

[8] Clark DL (2008). Checklist of the Mammals of Nech Sar National Park. Ethiopian Wildlife Conservation Authority, Addis Ababa, Ethiopia.

[9] Fetene A, Kumelachew Y, Ruediger P and Thomas H (2014). Study of Changes in Habitat Distribution and Habitat Structure of Nech Sar National Park, Ethiopia. Ecologia, 4 (1).

[10] Fetene A, Tsegaye T and Pananjay KT (2012). Impact of human activities on Ground Water Forests of Arba Minch: a case study from Ethiopia. International Journal of Basic and Applied Sciences, 1 (1): 54-60.

[11] Shimelis S, Tamrat B and Alemayehu M (2010). Floristic diversity and structure of Nech Sar National Park, Ethiopia. Journal of the drylands, 3 (1): 165-180.

[12] Negera A (2009). Protected area management, livelihood strategies and resource use conflicts in the Nech Sar National Park, Ethiopia. Oslo, Norway: Oslo University.

[13] Central Statistical Agency of Ethiopia (CSA) (2007). Population and Housing Census of Ethiopia. Addis Ababa, Ethiopia.

[14] Kothari CR (2004). Quantitative Techniques. New Delhi, Vikas Publishing House Pvt. Ltd.

[15] Cochran WG (1963). Sampling Techniques. 2nd Ed., New York: John Wiley and Sons, Inc. 
[16] Ethiopian Wildlife Conservation Authority EWCA (2007). Ethiopian Wildlife Conservation Authority Policy and Strategy. Addis Ababa, Ethiopia.

[17] Council of Ministers Regulations No. 163/2008. Council of Ministers Regulations to provide for Wildlife Development, Conservation and Utilization. Addis Ababa, Ethiopia.

[18] Development, Conservation and Utilization of Wildlife Proclamation No. 541/2007. A Proclamation to Provide for Development, Conservation and Utilization of Wildlife. Addis Ababa, Ethiopia.

[19] Ethiopian Biodiversity Institute (EBI) (2014). Ethiopia's Fifth
National Report to the Convention on Biological Diversity. Addis Ababa, Ethiopia.

[20] Sumit Chakravarty SK, Ghosh CP, Suresh AN, Dey and Gopal Shukla (2011). Deforestation: Causes, Effects and Control Strategies. Department of Forestry, Pomology \& Post Harvest Technology, Faculty of Horticulture, Uttar Banga Krishi Viswavidyalaya, Pundibari, ICAR Research Complex for Eastern Region, Research Center, Plandu Ranchi India.

[21] Chomitz KM, Buys P, Luca GD, Thomas TS and WertzKanounnikoff S (2007). Agricultural Expansion, Poverty Reduction and Environment in the Tropical Forests. World Bank Policy Research Report. World Bank, Washington DC. 